\title{
Ecology and ecosystem impacts of common buckthorn (Rhamnus cathartica): a review
}

\author{
Kathleen S. Knight · Jessica S. Kurylo • \\ Anton G. Endress · J. Ryan Stewart • \\ Peter B. Reich
}

Received: 5 June 2006/ Accepted: 3 January 2007 / Published online: 13 February 2007

(C) Springer Science+Business Media B.V. 2007

\begin{abstract}
In this review, we synthesize the current knowledge of the ecology and impacts of Rhamnus cathartica L., a shrub from Europe and Asia that is a successful invader in North America. Physiological studies have uncovered traits including shade tolerance, rapid growth, high photosynthetic rates, a wide tolerance of moisture and drought, and an unusual phenology that may give $R$. cathartica an advantage in the environments it invades. Its high fecundity, bird-dispersed fruit, high germination rates, seedling success in disturbed conditions, and secondary metabolite production may also contribute to its ability to rapidly increase in abundance and
\end{abstract}

K. S. Knight ( $ه)$

USDA Forest Service Northern Research Station, 359 Main Road, Delaware, OH 43015, USA email: Laca0023@umn.edu

\section{K. S. Knight}

Department of Ecology, Evolution, and Behavior, University of Minnesota, 100 Ecology Building, 1987 Upper Buford Circle, St. Paul, MN 55108, USA

\section{J. S. Kurylo}

Division for Ecology and Conservation Science, Illinois Natural History Survey, 1816 S. Oak Street, Champaign, IL 61820, USA

\section{A. G. Endress · J. R. Stewart}

Department of Natural Resources and Environmental Sciences, University of Illinois, 1101 W. Peabody, Urbana, IL 61801, USA impact ecosystems. $R$. cathartica impacts ecosystems through changes in soil $\mathrm{N}$, elimination of the leaf litter layer, possible facilitation of earthworm invasions, unsubstantiated effects on native plants through allelopathy or competition, and effects on animals that may or may not be able to use it for food or habitat.

Keywords Allelopathy · Buckthorn · Competition · Dispersal - Growth - Invasive . Nitrogen · Reproduction - Rhamnus cathartica

\section{Introduction}

Understanding the ecology of invasive species, as well as the mechanisms responsible for their impacts on ecosystems, is important for developing theory that will aid in conservation (Byers et al. 2002; Vázquez and Aragón 2002). Quantification of the impact of an invasive species would allow managers to prioritize control efforts, while

\footnotetext{
A. G. Endress

Division of Biodiversity and Ecological Entomology, Illinois Natural History Survey, 1816 S. Oak Street, Champaign, IL 61820, USA

P. B. Reich

Department of Forest Resources, University of Minnesota, 115 Green Hall, 1530 Cleveland Avenue N, St Paul, MN 55108-6112, USA
} 
identification of the attributes that allow native ecosystems to be invaded would assist in restoration (Byers et al. 2002).

Rhamnus cathartica L. (common buckthorn), a shrub or tree native to much of Europe and western Asia, has successfully invaded many habitats in North America (Kurylo et al., submitted). $R$. cathartica was brought to North America for planting as an ornamental shrub (Possessky et al. 2000) in the early 1800s or earlier (Torrey 1824). $R$. cathartica became naturalized throughout the Upper Midwestern and Northeastern United States and the Maritime provinces of Canada, invading many habitat types including open areas, forests, anthropogenic areas, and wetland edges (Kurylo et al., submitted). It seems to have an affinity for disturbed, fertile, calciumrich, open, moist areas (Gourley 1985), but these are not absolute requirements as it can tolerate both drought and partially flooded conditions (Stewart and Graves 2004).

The wide habitat tolerance of $R$. cathartica may contribute to its success (Seltzner and Eddy 2003). Ecological traits allow $R$. cathartica to succeed in these various environments and impact the ecosystems in which it becomes abundant. In this review, traits and ecosystem effects of $R$. cathartica are discussed and future research needs are identified.

\section{Population ecology and ecophysiology}

Shade tolerance and photosynthesis

The ability of $R$. cathartica to both tolerate shady conditions and grow quickly in open conditions may give it an advantage in forest gaps. Because there may be trade-offs between these traits (Grubb et al. 1996), understanding the factors that enable $R$. cathartica to survive in shade and out-grow other species in sun may provide mechanistic explanations for its invasion success. The photosynthetic capacity, carbon allocation, possible escape from natural enemies, and distinctive phenology of $R$. cathartica may play a role in these processes.

Rhamnus cathartica tolerates shady understory conditions (Archibold et al. 1997) and exhibits low mortality (Grubb et al. 1996; Knight 2006) in experimental settings at low light levels. Although growth and survival decrease in deep shade, even in very shady areas (1-2\% of full light in midsummer) many seedlings survive in field conditions (Knight 2006).

Even though it can tolerate shady environments, $R$. cathartica exhibits greater growth and abundance in areas with more light (Gourley and Howell 1984; Leitner 1985; Willert 2000; Scriver 2005) if moisture is not limiting (Wyckoff et al. 2005). In a study of 11 European woody species, $R$. cathartica was one of the faster-growing species (Grubb et al. 1996). In other studies, it grew faster than other shrubs, including Lonicera $\times$ bella Zabel, Prunus serotina Ehrh., Cornus racemosa Lam. (Harrington et al. 1989b), and closely related Frangula caroliniana (Walt.) Gray (synonym $R$. caroliniana) (Stewart and Graves 2004).

The rapid growth potential of $R$. cathartica may be due to its photosynthetic capacity. $R$. cathartica had the highest percent nitrogen in its leaves throughout the growing season when compared to P. serotina, Lonicera $\times$ bella, and C. racemosa, which was correlated with high rates of photosynthesis and carbon gain (Harrington et al. 1989a). However, in another study, greater growth of $R$. cathartica compared to $F$. caroliniana was not due to differences in photosynthetic rates (Stewart and Graves 2004). Greater carbon use efficiency or larger leaf area may have allowed greater growth of $R$. cathartica.

The 11 woody species tested by Grubb et al. (1996) showed a trade-off between shade tolerance and responsiveness to light (growth in $63 \%$ light $\div$ growth in $1.6 \%$ light). However, they noted that species with similar shade tolerance differed by almost one order of magnitude in light-responsiveness, and in the more shade-tolerant group of plants, $R$. cathartica was the most responsive. Although $R$. cathartica is shade tolerant, it is also uniquely able to take advantage of canopy openings.

The phenology of $R$. cathartica in North America may be advantageous in forest understories, where it photosynthesizes while the canopy is leafless (Harrington et al. 1989a). The leaves of $R$. cathartica flush earlier in the spring and remain later in the fall compared to four native cooccurring shrubs in Wisconsin (Barnes 1972). In 
southern Wisconsin, USA, $38 \%$ of $R$. cathartica's annual carbon gain occurred during 4 weeks when a native shrub, C. racemosa, was leafless (Harrington et al. 1989a). In Europe, the phenology of $R$. cathartica does not differ from that of other species (A. Gassman and J. Oleksyn, personal communication). $R$. cathartica was not listed as having long-lasting leaves in an experiment with 18 shrub species in Europe that found species with extended photosynthetic seasons to have an advantage (Kollman and Grubb 1999). Phenological adaptation to climate is thought to be constrained by trade-offs between maximizing carbon fixation during the growing season and avoiding frost damage in spring and fall (Saxe et al. 2001). Therefore, it is surprising that the phenology of an invader could be superior to that of native plants adapted to local conditions.

When invasive plants escape their natural enemies, they may be able to invade new habitats (e.g., DeWalt et al. 2004). Although R. cathartica inhabits a range of habitats in both its native and invasive ranges (Kurylo et al., submitted), it is usually found in open areas or forest edges in its native distribution (Gassmann 2005; L. Skinner and J. Oleksyn, personal communication), yet readily invades interiors of forests in North America (Gourley 1985; Leitner 1985; Heneghan et al. 2004). More research is needed to determine whether $R$. cathartica has expanded its habitat in North America due to escape from natural enemies, altered phenology, shade tolerance, or the ability to grow rapidly when canopy gaps appear.

\section{Fruit production}

Reproductive traits, including high fertility, may also contribute to the invasion success of $R$. cathartica. $R$. cathartica is generally dioecious (Darwin 1877), and exhibited sex ratios of six to seven female trees per male tree at one European site (Godwin 1943). Sex ratios in its invaded range have not been studied. The scented flowers of $R$. cathartica are pollinated by insects (Godwin 1943). Fruit production of $R$. cathartica has been described as "very prolific" (Godwin 1936) and "aggressive" (Archibold et al. 1997). The 5-7 mm drupes turn from green to black as they ripen. Drupe fresh mass may vary, with reported values ranging from $62 \mathrm{mg}$ under closed canopies (Gourley 1985) to 84-398 $\mathrm{mg}$ in open conditions (Sherburne 1972; Gourley 1985; K. S. Knight and P. B. Reich, unpublished).

The age at which $R$. cathartica shrubs may begin to reproduce varies. Reproduction has been reported in shrubs 9-20 years old in North America (Gourley 1985), and four (Grubb et al. 1999) and 11 years old (Godwin 1943) in Europe. After $R$. cathartica shrubs begin to reproduce, they continue to do so every year (Godwin 1943; Grubb et al. 1999). Fruit production and age and size at reproduction may depend on growing conditions. For example, $R$. cathartica growing in wetlands starts to bear fruit when still seedling-sized more often than conspecific plants in neighboring, better-drained oak woods (Gourley 1985). $R$. cathartica shrubs in wetlands also produce more fruit and larger fruit than conspecifics in neighboring oak woods (Gourley 1985). Differences in patterns of reproduction between Europe and North America have not been studied.

\section{Germination}

Factors that influence the germination of $R$. cathartica seeds may influence the success of a particular invasion. Germination occurs in the autumn and spring in Great Britain (Clapham et al. 1987) and in mid- to late summer in Minnesota (K. S. Knight, personal observation). Seeds germinate easily in the wild (Godwin 1936, 1943). Germination rates of $R$. cathartica seed are high: $85 \%$ for a North American population (Archibold et al. 1997) and 90-100\% in Europe (Godwin 1936). However, germination rates vary widely depending on the treatment of the seed.

Seeds must be free of pulp to germinate (Godwin 1943; Heit 1968; Gourley 1985; Archibold et al. 1997) and germinate best if they are fresh and have not been dried prior to planting (Dietz 1926; Godwin 1936). R. cathartica seeds exhibit physiological dormancy when dispersed (Baskin and Baskin 1998), and greater germination rates result when seeds are chilled, although recommendations on the stratification time required differ. Stratification at $4^{\circ} \mathrm{C}$ for $1-3$ months reduced germination times (Heit 1968; Deno 1993) and increased the percent of seeds that 
germinated (Stewart and Graves 2005). After stratification, exposing seeds to temperature cycles increased germination rates (T. Tylkowski, personal communication).

Effects of passage through a bird's digestive system are unclear. Acid scarification of 5, 10, and 15 min, simulating passage through a bird's digestive system, lessened the time until complete germination by 15 days without decreasing germination significantly (Gourley 1985). However, acid soaks ranging from $2 \mathrm{~min}$ (USDA 1948) to $1 \mathrm{~h}$ (Heit 1968) were found to be detrimental to germination.

Other factors that may affect germination include water logging, soil moisture, frost, leaf litter, light, and the conditions in which the parent tree was growing. Seeds from $R$. cathartica trees growing in oak (Quercus spp.) woods germinated 2 weeks faster and had higher germination rates than seeds from neighboring wetlands (Gourley 1985). Immersion of $R$. cathartica seeds in water for 2 months prevented germination (Gourley 1985; Archibold et al. 1997), but a 2-week immersion did not significantly lower germination rates (Gourley 1985). The highest germination rates occurred in moist but not saturated soil (Gourley 1985). Germination requirements may lead to patterns of $R$. cathartica occurrence with respect to soil moisture described in Kurylo et al. (submitted).

The affinity of $R$. cathartica for disturbed areas (Kurylo et al., submitted) may also be partially due to germination preferences. $R$. cathartica has higher seedling emergence rates in bare soil conditions than in the presence of herbaceous plants (Gill and Marks 1991) or leaf litter (Gourley and Howell 1984; Bisikwa 2005). Litter inhibits $R$. cathartica seedlings in the greenhouse and the field by decreasing irradiance (Bisikwa 2005). Deeper litter depths have stronger effects, causing an $80 \%$ reduction in seedling density in one study (Bisikwa 2005). Other studies that have examined the effect of irradiance on germination have found no effect (Godwin 1943) or greatest germination at intermediate light levels (Gourley 1985). Although litter inhibits germination, bare soil conditions may also have some disadvantages for seeds. In fields with bare soil, $R$. cathartica seeds are often heaved out of the ground by frost, where they may subsequently desiccate (Gill and Marks 1991). Understanding the many factors, including maternal effects, digestion by birds, and environmental conditions, that affect the rate and timing of germination facilitates prediction of conditions that lead to large seedling crops.

Seedling establishment

Invasion depends on establishment of seedlings in previously uninvaded areas, while dominance depends on regeneration in areas already invaded. $R$. cathartica seedlings excel at both, exhibiting low mortality, thriving in disturbed areas, and performing well near adult conspecifics. Because factors that affect the growth and survival of seedlings may affect the trajectory of the invasion, we examine biotic and abiotic influences on seedling success.

As expected from the prolific fruit production and high germination rates of $R$. cathartica, high densities of seedlings may be found near parent shrubs in invaded areas in North America (K. S. Knight, personal observation). The average number of seedlings beneath a dense $R$. cathartica stand in Saskatchewan, Canada was $>100 / \mathrm{m}^{2}$ and the seed bank averaged 620 seeds $/ \mathrm{m}^{2}$ (Archibold et al. 1997). Age structures of $R$. cathartica populations show that once a few plants mature, populations can grow quickly (Archibold et al. 1997). However, reports of dense seedling populations in Europe are lacking. A study in a plantation in England, where all mature R. cathartica shrubs were known to be reproducing yearly, found only 6.2 seedlings $/ \mathrm{m}^{2}$ under conspecific shrubs (Kollman and Grubb 1999). At four sites in Poland with 5-15 mature $R$. cathartica trees, no seedlings were observed near the parent trees during summer 2004, and only two seedlings were present in 2005 (K. S. Knight, personal observation).

Dominance and persistence of $R$. cathartica depends on the success of seedlings growing beneath conspecific adults in areas that are already invaded. Observations of greater densities of $R$. cathartica seedlings beneath mature $R$. cathartica shrubs than in surrounding areas have been made in both a European plantation (Kollman and Grubb 1999) and North American 
forests (Leitner 1985). These density patterns are not surprising given the prolific seed production of mature plants, however, the fate of the seedlings is both important and controversial.

Some studies have shown positive or neutral effects of mature $R$. cathartica shrubs on their seedlings. In North America, R. cathartica seedlings growing near mature conspecifics exhibited greater growth and survival than seedlings far from mature shrubs in similar light environments (Knight 2006). Unlike seedlings of four other species in an experimental garden in Europe, $R$. cathartica seedlings did not exhibit significantly higher mortality under conspecific shrubs than under other shrubs (Kollman and Grubb 1999). Other studies have suggested negative effects of mature $R$. cathartica on its seedlings. Gourley (1985) found many seedlings but few saplings under fruit-bearing $R$. cathartica bushes, but found many saplings around the perimeter of the bushes. She hypothesized that $R$. cathartica produces a shade too dense for its own seedlings to grow. Further evidence for seedling suppression comes from a study in which $R$. cathartica seedling numbers increased in plots where large $R$. cathartica shrubs were killed by chemical spraying compared to plots where the shrubs were left untouched (J. J. Moriarty, personal communication). The key to resolving the discrepancies between these studies may be the light levels experienced by the seedlings, which may be suppressed only in high-density, shady thickets. Further demographic studies in both areas with dense thickets and those with widely spaced mature trees are necessary to understand effects of mature $R$. cathartica on its seedlings.

In a study in Europe in which 18 species of naturally regenerating woody seedlings were surveyed, $R$. cathartica had the fifth-lowest mortality at $50 \%$ for all age classes and $76 \%$ for first-year seedlings within one growing season (Kollmann and Grubb 1999). Lower mortality was correlated with greater abundance. Mortality among $R$. cathartica seedlings grown from seed in forest gaps in Minnesota, USA, varied among years, ranging from $31 \%$ mortality for one cohort after 3 years of growth to $57 \%$ mortality for another cohort after 2 years of growth (Knight 2006). Potted $R$. cathartica seedlings in controlled environments had much lower mortality rates (per light level): $20 \%$ mortality at $0.3 \%$ light, $0 \%$ mortality at 1.6-63\% light (Grubb et al. 1996), and $4-11 \%$ mortality at $2-12 \%$ light (Knight 2006).

Mortality among seedlings may result from a variety of causes, including desiccation, herbivory, frost, fungal pathogens, and competition from other plant species. Mortality of $R$. cathartica seedlings in an experiment in England was mostly due to desiccation during a hot, dry summer, although fungal pathogens were implicated in some deaths (Kollmann and Grubb 1999). No herbivory was observed. In North America, desiccation may also be important: factors that may affect soil moisture, including soil fertility, soil texture, and percent organic matter, were correlated with seedling density of $R$. cathartica in Wisconsin forests (Leitner 1985). Other studies have shown $R$. cathartica seedling mortality due to frost damage on peat soils in Europe (Godwin 1943), frost heave in open corn fields, and $5-65 \%$ mortality due to predators in abandoned fields in North America (Gill and Marks 1991). In greenhouse experiments, seedling survival was greater in $25-50 \%$ light compared to $100 \%$ light (Gourley 1985). Seedlings in higher moisture treatments had greater survival but lower growth than seedlings in lower moisture conditions (Gourley 1985).

Reflecting the patterns of better seed germination in disturbed areas (Gourley and Howell 1984; Gill and Marks 1991; Bisikwa 2005), R. cathartica seedlings may grow better in disturbed areas where there is bare soil and native plant competition is modest. Survival and biomass of $R$. cathartica seedlings were reduced by competition from herbaceous plants in an old field community (Gill and Marks 1991). R. cathartica seedling size in forest understories was also reduced by both herbaceous plant (Willert 2000; Knight 2006) and overstory tree competition (Willert 2000; Scriver 2005; Knight 2006). These results are consistent with data that show decreased $R$. cathartica seedling abundance in areas with greater cover of understory herbaceous plants (Knight and Reich 2005) and native shrubs (Gourley 1985). Leaf litter may also limit $R$. cathartica seedling success. Five centimeters of 
leaf litter decreased seedling height by $40 \%$ and biomass by $50 \%$ compared to bare soil, with intermediate litter depths having intermediate results (Bisikwa 2005). The ability of $R$. cathartica seedlings to thrive in disturbed areas and both near and far from conspecific trees may enhance its invasive nature.

\section{Interspecific interactions}

Mycorrhizal and bacterial associations

Mutualistic soil symbionts may have positive effects on invasive plants (see review in Wolfe and Klironomos 2005). R. cathartica associates with vesicular arbuscular mycorrhizal (AM) fungi when grown in soils from its native (Godwin 1943; Gurney 1958; Knight 2006) and its invaded (Knight 2006) ranges. Although root infection depended on light levels, the percent of roots infected by AM fungi was similar in seedlings grown in soils from Minnesota, USA and Poland (Knight 2006). The benefits of mycorrhizal colonization, independent of effects of other soil biota, in the native vs. invaded ranges of $R$. cathartica or between $R$. cathartica and native plants have not been studied. Unlike other genera in the family Rhamnaceae, Rhamnus does not associate with the N-fixing actinomycete Frankia (J. O. Dawson, personal communication).

Secondary compounds-defense and allelopathy

Secondary compounds, particularly emodin, have been found in many Rhamnus L. species including R. cathartica (Trial and Dimond 1979; Francis et al. 1998; Tsahar et al. 2002) and may contribute to invasion success. Emodin may deter insects and other herbivores from eating leaves, bark and fruits, protect plants from pathogens and high light levels, have allelopathic effects on nearby plants, affect soil microorganisms, and affect fruit consumption and digestion by birds (Izhaki 2002).

Studies have isolated different forms of emodin in close relatives of $R$. cathartica and documented the effects of these chemicals on other species. Emodin in leaf tissue of $R$. alnifolia was found to deter insects both in lab trials and in field studies (Trial and Dimond 1979). Emodin in R. alaternus fruit pulp prevented seed predation by invertebrates and microbes without decreasing fruit removal by birds (Tsahar et al. 2002). The effects of secondary chemicals on insect herbivores and microbes and the identity of compounds in leaf tissues have not been examined in $R$. cathartica. Examination of these effects may be complicated by seasonal (Trial and Dimond 1979; Izhaki 2002) and environmental (Izhaki 2002) variation in emodin concentrations.

Emodin is present in $R$. cathartica fruit, and may serve multiple purposes including prevention of early consumption (Sherburne 1972). Emodin is found in unripe $R$. cathartica drupes (0.6$1.0 \mu \mathrm{g} /$ fruit), in seeds from both unripe and ripe fruit, but not in ripe drupes (Sherburne 1972). Birds and Peromyscus leucopus (mice) avoid eating unripe $R$. cathartica fruit as well as other fruits artificially coated with emodin (Sherburne 1972). If forced to ingest emodin or unripe fruit, these animals regurgitated the meal or produced loose, watery stools. Although 11 species of birds readily ate ripe $R$. cathartica fruit in this study, no negative effects of ripe fruit on birds were mentioned.

Allelopathic effects of exudates from $R$. cathartica leaf litter (Archibold et al. 1997), roots (Archibold et al. 1997; Seltzner and Eddy 2003), bark, leaves, and fruit (Seltzner and Eddy 2003) have been examined with Medicago sativa (alfalfa), tomato, lettuce, and radish seeds. Exudates from the roots, bark, and leaf litter had no effect on seed germination (Archibold et al. 1997; Seltzner and Eddy 2003). Leaf exudates reduced alfalfa seed germination to $58 \%$ (a $42 \%$ reduction) while fruit exudates reduced germination to $<1 \%$ (Seltzner and Eddy 2003). Because many $R$. cathartica drupes may fall beneath the parent tree (Archibold et al. 1997), it is possible that emodin in fruit could have detrimental effects on native plants beneath $R$. cathartica canopies. The strength of allelopathic effects may vary seasonally as well as among individual $R$. cathartica trees (C. Wilson, personal communication). More research is needed to understand the ecological significance of secondary chemicals produced by $R$. cathartica, which may play a role in 
suppression of native plants, protection from herbivores, and protection of unripe fruits.

\section{Interactions with natural enemies}

Escape from natural enemies is often invoked to explain the success of invasive species, however, it is unclear whether $R$. cathartica has escaped from enemies, including pathogens, insect herbivores, and mammalian herbivores. Further research is needed before conclusions can be reached regarding enemy escape, however, the information that does exist is outlined below.

An experiment examining effects of soil biota from Poland and Minnesota, USA, did not find evidence of escape from soil pathogens (Knight 2006). The only pathogen known to kill $R$. cathartica is a phytoplasma disease found in Germany (Mäurer and Seemüller 1996). Further studies, examining multiple types of pathogens and other areas of the native and invaded ranges of $R$. cathartica, are needed.

Many species of insects associate with $R$. cathartica in Europe (Hulme 1914; Gurney 1958; Malicky et al. 1970; Gassmann 2005) where several species of moths and psyllids seem to be specific to $R$. cathartica (Gassmann 2005). Determination of their suitability for biocontrol is ongoing (Gassmann 2005). In contrast, while some generalist North American insects feed on $R$. cathartica, they seem to inflict little damage (Vanveldhuisen et al. 2005). $R$. cathartica experiences less herbivory than co-occurring native plants in North America (Heneghan 2005). These patterns suggest that $R$. cathartica may have escaped from host-specific insect enemies, however, more research is needed.

Rhamnus cathartica saplings may be protected from mammalian herbivores. Of 22 abundant woody species in New England, USA, R. cathartica was one of a few that were avoided by the cottontail rabbit, Sylvilagus floridanus mallurus Thomas, during two winters (Sweetman 1944, 1949). Anecdotally, beavers were also observed to avoid R. cathartica (Hughes and Cass 1997). However, anecdotal evidence shows that younger $R$. cathartica seedlings may be damaged or killed by herbivores. A European rabbit species in England severely damaged $70 \%$ of 2 -year-old
$R$. cathartica seedlings growing in an outdoor experiment (Grubb et al. 1999) and unknown predators killed seedlings in abandoned fields (Gill and Marks 1991).

\section{Dispersal}

Dispersal by vertebrates may contribute to the invasiveness of plant species (Rejmánek 1996). Long-distance dispersal, primarily by birds, likely contributes to the ability of $R$. cathartica to establish new populations in sites far from established populations. Birds are considered to be the main dispersal agents of $R$. cathartica seeds (Godwin 1936; Gourley 1985; Archibold et al. 1997), as evidenced by the association of $R$. cathartica with fencerows, hedges (Archibold et al. 1997), and perch trees (Gourley 1985). Many species of birds in both Europe and North America have been observed feeding on the fruit (Godwin 1943; Ridley 1930; Sherburne 1972; Gourley 1985; Whelan and Dilger 1992; Schmidt and Whelan 1999). In a 2-year study in New York, USA, $64-100 \%$ of the fruit on $R$. cathartica shrubs at two sites were consumed by birds (Sherburne 1972). However, Archibold et al. (1997) found that $90 \%$ of the fruits and seeds in his study fell below the canopies of female shrubs in Saskatchewan, Canada, which suggests that birds may not always be effective dispersal agents. Even though many bird species have been seen eating the fruit, birds may prefer fruits of other species. During the winter in England, an "abundance of dried berries" remained on $R$. cathartica shrubs even though fruit of $F$. alnus Mill., a closely related species, had all been eaten (Godwin 1936).

Rodents may also disperse $R$. cathartica seeds (Godwin 1936, 1943; Gill and Marks 1991). $R$. cathartica seeds (along with Fraxinus americana seeds) placed on the ground experienced lower predation by rodents than $C$. racemosa (gray dogwood) and Viburnum dentatum (arrowwood) in open areas; but the seeds were all taken within 6 days when under herbaceous cover (Gill and Marks 1991). Mus sylvaticus (field mice) did not take ripe fruits from trays placed on the ground, but readily removed seeds from the trays (Godwin 1936). Although mouse predation of seeds may impede seedling recruitment, stores of 
buried seeds that are forgotten by mice will germinate (Godwin 1936).

\section{Ecosystem impacts}

In North America, $R$. cathartica forms dense monospecific thickets over large areas. In forests, it sometimes becomes the dominant understory species (Archibold et al. 1997), comprising 50\% of all understory plant stems (Wyckoff 2005) with densities reaching 34,600 sapling stems per hectare (J. J. Moriarty, personal communication). Although no quantitative evidence is available to describe $R$. cathartica abundance in European habitats, scientists who have observed $R$. cathartica in eastern Austria, Czech Republic (A Gassman, personal communication), Southern Germany, Switzerland (L. C. Skinner and A. Gassman, personal communication), Spain, Bulgaria, Greece, Ukraine (A. Boratynski, personal communication), and Poland (J. Oleksyn, personal communication) report that large, dense thickets do not usually occur (but see Godwin 1936). The extreme densities of $R$. cathartica in North America may explain why ecosystem impacts have only been noted in North America.

Impacts on leaf litter and soil processes

One of the most important impacts of $R$. cathartica is the alteration of ecosystem processes, including decomposition and $\mathrm{N}$ and $\mathrm{C}$ cycling. $R$. cathartica leaf litter is high in $\mathrm{N}$, with concentrations of $1.1-1.9 \% \mathrm{~N}$ in senesced leaves (Kennedy 2000) and 2.2\% N in leaf litter (Heneghan et al. 2002). These levels were greater than other non-N-fixing trees, including Populus deltoides, P. serotina, Acer saccharum, Betula nigra, and Quercus spp. (Kennedy 2000; Heneghan et al. 2002) and similar to those of related N-fixing plants (Kennedy 2000). This high-N litter decomposes rapidly, changing soil-N pools and the structure of forest floor communities (Heneghan et al. 2002, 2004). Litter of $R$. cathartica decomposed faster than litter of $P$. deltoides, $P$. serotina, or Quercus spp. (Heneghan et al. 2002). Mixing these other litter types with $R$. cathartica litter caused the other litter types to decompose more rapidly (Heneghan et al. 2002). Both ripe and unripe drupes of $R$. cathartica have greater $\% \mathrm{~N}$ $(1.6-2.1 \%)$ than fruits of 11 other native and exotic woody plants (Sherburne 1972). Effects of these high-N drupes on decomposition and soil $\mathrm{N}$ have not been studied, but may be relevant in cases where many drupes fall to the ground uneaten.

The rapid litter decomposition can cause bare soil conditions beneath $R$. cathartica stands. Kollmann and Grubb (1999) found that litter was sparse under $R$. cathartica compared to litter under other shrubs. Heneghan et al. (2004) found that the late-summer litter layer in more open buckthorn-free areas had two to six times greater biomass (depending on the season) than the litter under $R$. cathartica thickets. The soil fauna under $R$. cathartica was also affected. $R$. cathartica litter exhibited rapid rates of arthropod colonization, which may lead to rapid decomposition of the litter layer, diminishing food sources too early in the year, and, ultimately, a collapse in the soil arthropod community (Heneghan et al. 2002) which forms the base of food webs that support mammals and birds (Heneghan 2003).

High-N litter inputs caused a doubling of \% soil $\mathrm{N}$ under $R$. cathartica thickets compared to surrounding forested areas (Heneghan et al. 2004, 2006). In dense thickets, the increased $\mathrm{N}$ was mostly in the form of organic $\mathrm{N}$, which is not immediately available to plants. Forms of $\mathrm{N}$ available to plants, including $\mathrm{NO}_{3}$ and $\mathrm{NH}_{4}$, were similar (Heneghan et al. 2004). Other soil properties differed in $R$. cathartica thickets: $\mathrm{pH}$ was significantly higher, total carbon increased by $80 \%$, and gravimetric water content was $40 \%$ higher (Heneghan et al. 2004, 2006, but see Kasmer and Shefferson 2002).

However, in earlier stages of invasion near single, mature $R$. cathartica trees, $\mathrm{N}$ mineralization and soil $\mathrm{NO}_{3}$ were greater than in areas away from the mature trees (Knight 2006). R. cathartica seedling growth was positively correlated with soil $\mathrm{NO}_{3}$ levels, suggesting that soil fertilization by mature trees may cause greater growth of nearby seedlings.

Due to a lack of pre-invasion data, comparisons of soil properties in invaded vs. uninvaded areas are unable to distinguish between 
differences due to the invasive species and differences that existed prior to invasion. However, the evidence suggests that $R$. cathartica alters soil properties, which could have implications for invaded areas. Changes in ecosystem properties may have indirect effects on other species and may persist even after $R$. cathartica is removed. This legacy effect could have implications for restoration efforts for cleared sites (Heneghan et al. 2004), although species effects on biogeochemistry may be short-lived once composition changes (Dijkstra et al. 2006; Heneghan et al. 2006).

\section{Effects on native plants}

In North America, there are numerous anecdotal descriptions of dense $R$. cathartica thickets associated with the loss of native species (Gourley and Howell 1984; Boudreau and Wilson 1992) but few studies that have quantified these patterns. It is difficult to separate the effects of $R$. cathartica from co-occurring factors, such as exotic earthworms (Bohlen et al. 2004; Hale et al. 2005) and deer overpopulation (Rooney and Waller 2003), that may also lead to declines in understory species. Effects of $R$. cathartica on native plants have been examined with three types of studies: surveys, $R$. cathartica thicket removal, and controlled experiments under individual $R$. cathartica trees.

Two surveys have shown light and vegetation differences in naturally invaded and uninvaded plots. Light penetration to shorter vegetation was decreased by $R$. cathartica shrubs (Leitner 1985; Alsum 2003) but not by other shrub species (Alsum 2003). The cover of herbaceous species was lower in areas with $R$. cathartica and negatively correlated with the density of $R$. cathartica (Alsum 2003 but see Leitner 1985). The composition of the plant community in plots with $R$. cathartica also differed: more species of weedy and exotic species, fewer conservative plant species (i.e., species that are specific to certain habitats and often intolerant of anthropogenic disturbance), greater cover of invasive Lonicera spp., and lower richness of herbaceous species were associated with $R$. cathartica invasion (Alsum 2003 but see Leitner 1985). However, these observations cannot attribute these effects to $R$. cathartica invasion (e.g., perhaps $R$. cathartica preferentially invades areas with these characteristics) and do not separate the effects of shading from the effects of competition for light, water, and nutrients, as well as the effects of potential allelopathy.

Some evidence of effects of $R$. cathartica on native herbaceous plant species comes from $R$. cathartica removal experiments. Removal of $R$. cathartica shrubs increased light penetration to understory plants (L. Heneghan and L. Umek, unpublished). In plots where $R$. cathartica was removed and yearly controlled burns were used to control $R$. cathartica seedlings, herbaceous diversity was twice that of unmanipulated plots (J. Moriarty, personal communication). However, some native woody plants were negatively impacted by fire. Another study found native plants reappearing in areas that had been cut and treated, however, other invaders also appeared (Boudreau and Wilson 1992). Although the latter studies both showed positive responses of native plants, the mechanisms underlying the effects are unknown.

Experimental studies of individual $R$. cathartica shrubs have not shown negative effects on understory plants. Individual $R$. cathartica shrubs were not detrimental to seedlings of other woody species in an experiment in England (Kollman and Grubb 1999). Mortality (41\%) and density (12-17 $\mathrm{m}^{-2}$ ) of woody seedlings growing under individual $R$. cathartica shrubs, as well as light levels and soil moisture beneath the shrubs, were similar to those of other shrub species (Kollman and Grubb 1999). In a study in Minnesota, USA, plots in similar light environments planted with ten species of native woodland forbs near individual $R$. cathartica trees exhibited greater native percent cover than those away from $R$. cathartica trees after 3 years of growth (Knight 2006). The plots did not differ in diversity of the forbs, so the percent cover increase represented an increase in the size of the native plants without elimination of species. This suggests that negative, allelopathic effects may be ameliorated by positive effects (e.g., increased soil $\mathrm{NO}_{3}$ ) at this early stage of invasion (Knight 2006). 
Although the surveys and removal experiments do not definitively implicate $R$. cathartica in the decline of native species, and the controlled experiments under individual $R$. cathartica trees did not show detrimental effects on understory plants, it is quite likely that $R$. cathartica thickets have negative effects on native species in North America. Perhaps the two most likely mechanisms for such decline involve resource competition and allelopathy; the magnitude of both of which would be highly dependent on the abundance of $R$. cathartica in any given area. Dense shrub layers, regardless of species, can limit juvenile tree species survival and growth due to shading (Coates et al. 1991; Lei et al. 2002; Gorchov and Trisel 2003) and below-ground competition (Gorchov and Trisel 2003), so dense thickets of $R$. cathartica would probably have such effects. Additionally, allelopathic effects have been hypothesized as a possible reason for the lack of vegetation in the understory of $R$. cathartica (Gourley 1985; Boudreau and Wilson 1992). However, allelopathic effects have only been found on alfalfa (Seltzner and Eddy 2003). Controlled experiments to quantify and determine the mechanisms underlying the effects of $R$. cathartica thickets on native species are needed.

In contrast to North America, R. catharica is reportedly uncommon in Europe (A. Gassman et al., personal communication) and therefore probably does not have effects on understory plants over large areas. The only example we could find of a European ecosystem with abundant $R$. cathartica was the description of Wicken Fen in England (Godwin 1936). From this description, it is apparent that $R$. cathartica does dominate some ecosystems in its native range and is associated with the reduction of other plant species. However, this situation is rare in Europe (Rodwell et al. 1991).

\section{Effects on animals}

Rhamnus cathartica may have both direct and indirect effects on the many species that use it, or are unable to use it, as a food source. In Europe, many insect herbivores, including specialists, feed on $R$. cathartica (Malicky et al. 1970; Gassman 2005). However, in North America, insect herbivores prefer native species (Heneghan 2005) and only generalists have been observed on $R$. cathartica (Vanveldhuisen et al. 2005). $R$. cathartica does not appear to be a major food source for mammalian herbivores on either continent. As mentioned earlier, European rabbits eat $R$. cathartica seedlings (Grubb et al. 1999), however, they, as well as cottontail rabbits (S. floridanus mallurus) (Sweetman 1944, 1949) and beavers (Hughes and Cass 1997) avoid older $R$. cathartica saplings. Mice and other rodents may consume $R$. cathartica seeds (Godwin 1936, 1943; Gill and Marks 1997), but this may cause diarrhea (Sherburne 1972). The effects of $R$. cathartica thickets on insect and mammal populations have not been examined, however, one might speculate that if $R$. cathartica causes declines in understory species that are more palatable, the herbivores may be negatively impacted as well.

As mentioned earlier, both European and North American bird species eat the fruit, although it may not be their preferred food source (Godwin 1943; Ridley 1930; Whelan and Dilger 1992; Schmidt and Whelan 1999). For North American bird species, positive effects of $R$. cathartica as a food source may be offset by negative effects. Apfelbaum and Haney (1987) claim that bird species diversity declines as invasion of $R$. cathartica progresses, however, no statistical analyses were provided. Turdus migratorius (American robin) and Hylocichla mustelina (wood thrush) nest in R. cathartica and L. maackii shrubs (Schmidt and Whelan 1999). When birds nest in the exotic shrubs, they experience a higher rate of predation compared to birds nesting in native shrubs (Schmidt and Whelan 1999). When invasive plants replace native plants and provide food and nest sites, native fauna may suffer from eradication efforts that are not accompanied by restoration of native plants (Whelan and Dilger 1992; Zavaleta et al. 2001). Research examining the effects of $R$. cathartica, and its removal, on native animal species is needed to inform restoration and management efforts.

Interactions with invasive earthworms

Effects of $R$. cathartica invasion may be compounded by interactions with other invasive 
species as many areas invaded by $R$. cathartica may have also experienced other changes during the same time period. It is difficult to distinguish the effects of $R$. cathartica from those of simultaneous invaders which may have mutualistic interactions with $R$. cathartica, causing an "invasion meltdown" (e.g., Simberloff and Von Holle 1999).

European earthworms have invaded many areas of North America that were previously earthworm-free (James 1995). Earthworms reduce the leaf litter layer and affect nutrient cycling, which in turn affects native soil fauna and herbaceous plant species (Bohlen et al. 2004; Hale et al. 2005). Leaf litter that is high in $\mathrm{N}$ (Hendriksen 1990) and Ca (Reich et al. 2005) may be an attractive food source for earthworms, potentially facilitating denser earthworm populations. Earthworms appear to prefer $R$. cathartica leaf litter to that of Quercus spp. (oak), have large effects on decomposition of $R$. cathartica litter (Heneghan 2005), and attain greater biomass and abundance in areas dominated by $R$. cathartica (Heneghan et al. 2006). The bare soil conditions that earthworms create are ideal for $R$. cathartica seed germination, which is inhibited by leaf litter (Bisikwa 2005; Gill and Marks 1991; Gourley and Howell 1984). Both of these invaders are thought to have large effects on native plant populations, and it is difficult to separate the effects of $R$. cathartica, earthworms, and native deer populations.

\section{Conclusions}

Understanding the biology of $R$. cathartica may shed light on the mechanisms that underlie its invasive nature and impacts on ecosystems. Traits including shade tolerance, rapid growth, high photosynthetic rates, unique leaf phenology, potential escape from natural enemies, prolific reproduction, bird-dispersed fruit, high germination rates, seedling survival in bare soil conditions, and secondary metabolite production may give $R$. cathartica an advantage in the environments it invades. $R$. cathartica can invade a variety of ecosystems, and it may have effects on leaf litter, nutrient cycling, soil processes, invasive earthworms, soil biota, plants, and animals. The magnitude and even the direction of effects of $R$. cathartica on native plants and animals in the disturbed ecosystems that make up much of eastern North America are not well understood, and more research is needed in this area. Quantifying these effects is difficult in the face of other forces of change, such as earthworm invasion, deer overpopulation, climate change, and anthropogenic disturbance. However, a better understanding of these effects is necessary in order to make informed management decisions and set realistic restoration goals.

Acknowledgments We thank everyone who shared with us their observations and unpublished studies as well as associate editor Dr Ingrid Parker and the anonymous reviewers whose suggestions greatly improved this manuscript.

\section{References}

Alsum EM (2003) Fifty years later: an assessment of the influence of common buckthorn (Rhamnus cathartica L.) and of change in overstory vegetation in several floodplain forests of the Lower Wisconsin State Riverway. Master's Thesis, University of Wisconsin, Madison, $123 \mathrm{pp}$

Apfelbaum SL, Haney A (1991) Management of degraded oak savanna remnants in the Upper Midwest: preliminary results from three years of study. In: John Ebinger (ed) Proceedings of the Oak Woods management workshop, Peoria, pp 81-89

Archibold OW, Brooks D, Delanoy L (1997) An investigation of the invasive shrub European Buckthorn, Rhamnus cathartica L., near Saskatoon, Saskatchewan. Can Field Nat 111:617-621

Barnes WJ (1972) The autecology of the Lonicera $\times$ bella complex. Dissertation, University of Wisconsin

Baskin CC, Baskin JM (1998) Seeds: ecology, biogeography, and evolution of dormancy and germination. Academic Press, New York, p. 666

Bisikwa J (2005) Establishment and management of European buckthorn (Rhamnus cathartica L.). Dissertation, University of Minnesota, $117 \mathrm{pp}$

Bohlen PJ, Scheu S, Hale CM et al (2004) Non-native invasive earthworms as agents of change in northern temperate forests. Front Ecol Environ 2:427-435

Boudreau D, Wilson G (1992) Buckthorn research and control at Pipestone National Monument (Minnesota). Restor Manage Notes 10:94-95

Byers JE, Reichard S, Randall JM et al (2002) Directing research to reduce the impacts of nonindigenous species. Conserv Biol 16:630-640

Clapham AR, Tutin TG, Warburg EF (1987) Flora of the British Isles. 3rd edn. Cambridge University Press, Great Britain, pp. 688 
Coates KD, Emmingham WH, Radosevich SR (1991) Conifer-seedling success and microclimate at different levels of herb and shrub cover in a RhododendronVaccinium menziesia community of south central British Columbia. Can J For Res 21:858-866

Darwin C (1877) The different forms of flowers on plants of the same species. John Murray, London, pp. 352

Deitz SM (1926) The alternate hosts of crown rust, Puccinia coronata Corda. J Agric Res 33:953-970

Deno NC (1993) Seed germination theory and practice. 2nd edn. State College, Pennsylvania pp. 242

DeWalt SJ, Denslow JS, Ickes K (2004) Natural-enemy release facilitates habitat expansion of the invasive tropical shrub Clidemia hirta. Ecology 85(2):471-483

Dijkstra FA, Wrange K, Hobbie SE et al (2006) Tree patches show higher $\mathrm{N}$ losses but maintain higher $\mathrm{N}$ availability than grassland patches in a frequently burned oak savanna. Ecosystems 9:441-452

Francis GW, Aksnes DW, Holt O (1998) Assignment of the ${ }^{1} \mathrm{H}$ and ${ }^{13} \mathrm{C}$ NMR spectra of anthraquinone glycosides from Rhamnus frangula. Magn Reson Chem 36:769-772

Gassmann A (2005) Developing biological control of buckthorns. In: Skinner LC (ed) Proceedings: symposium on the biology, ecology and management of garlic mustard (Alliaria petiolata) and European buckthorn (Rhamnus cathartica), St Paul, May 2005. USDA Forest Service Publication, St Paul, pp 55-57

Gill DS, Marks PL (1991) Tree and shrub seedling colonization of old fields in central New York. Ecol Monogr 61:183-205

Godwin H (1936) Studies in the ecology of Wicken Fen III: the establishment and development of fen scrub (carr). J Ecol 24:82-116

Godwin H (1943) Biological flora of the British Isles: Rhamnaceae. J Ecol 31:66-92

Gorchov DL, Trisel DE (2003) Competitive effects of the invasive shrub, Lonicera maackii (Rupr.) Herder (Caprifoliaceae), on the growth and survival of native tree seedlings. Plant Ecol 166:13-24

Gourley LC (1985) A study of the ecology and spread of Buckthorn (Rhamnus cathartica L.) with particular reference to the University of Wisconsin Arboretum. Dissertation, University of Wisconsin, Madison, 166 pp

Gourley LC, Howell E (1984) Factors in Buckthorn invasion documented; control measures checked (Wisconsin). Restor Manage Notes 2:87

Grubb PJ, Lee WG, Kollmann J et al (1996) Interaction of irradiance and soil nutrient supply on growth of seedlings of ten European tall-shrub species and Fagus sylvatica. J Ecol 84:827-840

Grubb PJ, Kollmann J, Lee WG (1999) A garden experiment on susceptibility to rabbit grazing, sapling growth rates, and age at first reproduction for eleven European woody species. Plant Biol 1:226-234

Gurney R (1958) Trees of Britain. Faber and Faber, London pp. 228

Hale CM, Frelich LE, Reich PB (2005) Exotic European earthworm invasion dynamics in northern hardwood forests of Minnesota, USA. Ecol Appl 15:848-860
Harrington RA, Brown BJ, Reich PB (1989a) Ecophysiology of exotic and native shrubs in southern Wisconsin I. Oecologia 80:356-367

Harrington RA, Brown BJ, Reich PB et al (1989b) Ecophysiology of exotic and native shrubs in southern Wisconsin II: annual growth and carbon gain. Oecologia 80:368-373

Heit CE (1968) Propagation from seed. Am Nurseryman 128:8-10, 70-80

Hendriksen NB (1990) Leaf litter selection by detritivore and geophagous earthworms. Biol Fertil Soils 10:17-21

Heneghan L (2003) And when they got together...impacts of Eurasian earthworm and invasive shrubs on Chicago woodland ecosystems. Chicago Wilderness J 1:27-31

Heneghan L (2005) Impact of Rhamnus cathartica (European Buckthorn) on Midwestern woodland ecosystems and the implications for restoration management. In: Skinner LC (ed) Proceedings: symposium on the biology, ecology and management of garlic mustard (Alliaria petiolata) and European buckthorn (Rhamnus cathartica), St Paul, May 2005. USDA Forest Service Publication, St Paul, pp 42-48

Heneghan L, Clay C, Brundage C (2002) Rapid decomposition of Buckthorn litter may change soil nutrient levels. Ecol Restor 20:108-111

Heneghan L, Rauschenberg C, Fatemi F et al (2004) European Buckthorn (Rhamnus cathartica) and its effects on some ecosystem properties in an urban woodland. Ecol Restor 22:275-280

Heneghan L, Faterni R, Umek L et al (2006) The invasive shrub European buckthorn (Rhamnus cathartica, L.) alters soil properties in Midwestern U.S. woodlands. Appl Soil Ecol 32:142-148

Heneghan L, Steffen J, Fagen K (2006) Interactions of an introduced shrub and introduced earthworms in an Illinois urban woodland: Impact on leaf litter decomposition. Pedobiologia 50:543-551

Hughes JW, Cass WB (1997) Pattern and process of a floodplain forest, Vermont, USA: predicted responses of vegetation to perturbation. J Appl Ecol 34:594-612

Hulme FE (1914) Wild fruits of the country-side. F.A. Stokes Co., New York pp. 221

Izhaki I (2002) Emodin-a secondary metabolite with multiple ecological functions in higher plants. New Phytol 155:205-217

James S (1995) Systematics, biogeography and ecology of nearctic earthworms from eastern central southern and southwestern United States. In: Hendrix PF (ed) Earthworm ecology and biogeography in North America. Lewis, Boca Raton, pp 29-52

Kasmer J, Shefferson R (2002) Effects of removing an invasive understory shrub on growth of canopy trees in northeastern Illinois. Ecol Restor 20:209-210

Kennedy GJ (2000) Low foliar nitrogen resorption proficiency in nitrogen-fixing, temperate deciduous trees and shrubs. Dissertation, University of Illinois at Urbana Champaign, 35 pp

Knight KS (2006) Factors that influence invasion success of two woody invaders of forest understories. Dissertation, University of Minnesota, $161 \mathrm{pp}$ 
Knight KS, Reich PB (2005) Opposite relationships between invasibility and native species richness at patch versus landscape scales. Oikos 109:81-88

Kollmann J, Grubb PJ (1999) Recruitment of fleshyfruited species under different shrub species: control by under-canopy environment. Ecol Res 14:9-21

Lei TT, Semones SW, Walker JF et al (2002) Effects of Rhododendron maximum thickets on tree seed dispersal, seedling morphology, and survivorship. Int J Plant Sci 163:991-1000

Leitner LA (1985) An alien shrub in a changing landscape: the European buckthorn (Rhamnus cathartica L.) in southeastern Wisconsin. Dissertation, University of Wisconsin, $403 \mathrm{pp}$

Malicky H, Sobhian R, Zwolfer H (1970) Investigations on the possibilities of a biological control of Rhamnus cathartica in Canada: host ranges, feeding sites, and phenology of insects associated with European Rhamnaceae. Z Angew Entomol 65:77-97

Mäurer R, Seemüller E (1996) Witches' broom of Rhamnus catharticus: a new phytoplasma disease. J Phytopathol 144:221-223

Possessky SL, Williams CE, Moriarty WJ (2000) Glossy Buckthorn, Rhamnus frangula L.: a threat to riparian plant communities of the northern allegheny plateau (USA). Nat Area J 20:290-292

Reich PB, Oleksyn J, Modrzynski J et al (2005) Tree species, litter calcium, earthworms and soil properties. Ecol Lett 8:811-818

Rejmánek M (1996) A theory of seed plant invasiveness: the first sketch. Biol Conserv 78:171-181

Ridley NH (1930) The dispersal of plants throughout the world. L.R. Reeve and Company Ltd, Ashford Kent, pp. 744

Rodwell JS, Pigott CD, Ratcliffe DA et al (1991) British plant communities, vol 1 (woodlands and scrub). Cambridge University Press, Cambridge, pp. 395

Rooney TP, Waller DM (2003) Direct and indirect effects of white-tailed deer in forest ecosystems. For Ecol Manage 181:165-176

Saxe H, Cannell MGR, Johnsen O et al (2001) Tree and forest functioning in response to global warming. New Phytol 149:369-400

Schmidt KA, Whelan CJ (1999) Effects of exotic Lonicera and Rhamnus on songbird nest predation. Conserv Biol 13:1502-1506

Scriver BM (2005) Consequences of oak savanna restoration techniques on the re-invasion of non-native invasive shrubs, particularly Rhamnus cathartica L. (common buckthorn). Dissertation, University of Wisconsin, Madison, $153 \mathrm{pp}$

Seltzner S, Eddy TL (2003) Allelopathy in Rhamnus cathartica, European buckthorn. Mich Bot 42:51-61

Sherburne JA (1972) Effects of seasonal changes in the abundance and chemistry of the fleshy fruits of northeastern woody shrubs on patterns of exploitation by frugivorous birds. Dissertation, Cornell University, $157 \mathrm{pp}$
Simberloff D, Von Holle M (1999) Synergistic interactions of nonindigenous species: invasional meltdown? Biol Invasions 1:21-32

Stewart JR, Graves WR (2004) Photosynthesis and growth of Rhamnus caroliniana during drought and flooding: comparisons to the invasive Rhamnus cathartica. HortScience 39:1278-1282

Stewart JR, Graves WR (2005) Seed germination of Rhamnus caroliniana: implications for ecology and horticulture. HortScience 40:767-770

Sweetman HL (1944) Selection of woody plants as winter food by the cottontail rabbit. Ecology 25:467-472

Sweetman HL (1949) Further studies of the winter feeding habits of cottontail rabbits. Ecology 30:371-376

Torrey J (1824) A flora of the northern and middle sections of the United States: or, a systematic arrangement of all the plants hitherto discovered in the United States north of Virginia. vol 1. T. and J. Swords, New York, pp. 513

Trial H Jr, Dimond JB (1979) Emodin in buckthorn: a feeding deterrent to phytophagous insects. Can Entomol 111:207-212

Tsahar E, Friedman J, Izhaki I (2002) Impact on fruit removal and seed predation of a secondary metabolite, emodin, in Rhamnus alaternus fruit pulp. Oikos 99:290-299

USDA Forest Service (1948) Woody-plant seed manual. USDA Misc. Publication \#654

Vanveldhuisen MV, Ragsdale DW, Skinner LC (2005) Survey of insect fauna on common buckthorn, Rhamnus cathartica. In: Skinner LC (ed) Proceedings: symposium on the biology, ecology and management of garlic mustard (Alliaria petiolata) and European buckthorn (Rhamnus cathartica), St Paul, May 2005. USDA Forest Service Publication, St Paul, pp 58-61

Vázquez DP, Aragón R (2002) Introduction. Biol Invasions $4: 1-5$

Whelan C, Dilger ML (1992) Invasive, exotic shrubs: a paradox for natural area Managers? Nat Area J 12:109-110

Willert JM (2000) Oak savanna restoration: management techniques to inhibit exotic shrub reinvasion. Dissertation, University of Wisconsin, Madison, $142 \mathrm{pp}$

Wolfe BE, Klironomos JN (2005) Breaking new ground: soil communities and exotic plant invasion. BioScience 55:477-487

Wyckoff P, Jansen R, Patten R (2005) The European buckthorn (Rhamnus cathartica) invasion in west central Minnesota. In: Skinner LC (ed) Proceedings: symposium on the biology, ecology and management of garlic mustard (Alliaria petiolata) and European buckthorn (Rhamnus cathartica), St Paul, May 2005. USDA Forest Service Publication, St Paul, pp 49-52

Zavaleta ES, Hobbs RJ, Mooney HA (2001) Viewing invasive species removal in a whole-ecosystem context. Trends Ecol Evol 16:454-459 